\title{
Differential impacts of 2016 coral bleaching on coral reef benthic communities at Sekotong Bay, Lombok Barat, Indonesia
}

\author{
IMAM BACHTIAR ${ }^{1,2, \boldsymbol{v}}$, TRI ARYONO HADI ${ }^{3}$ \\ ${ }^{1}$ Department of Science Education, Faculty of Teacher Training and Education, Universitas Mataram. Jl. Majapahit 62, Mataram 83125, West Nusa \\ Tenggara, Indonesia. Tel./fax. +62-370-623873. "email: imambachtiar@unram.ac.id \\ ${ }^{2}$ Program of Science Education, Graduate Program, Universitas Mataram. Jl. Majapahit 62 Mataram 83125, Nusa Tenggara Barat \\ ${ }^{3}$ Research Center for Oceanography, Indonesian Institute of Sciences. Jl. Ancol Timur, Jakarta Utara 14430, Jakarta, Indonesia
}

Manuscript received: 11 November 2018. Revision accepted: 30 January 2019.

\begin{abstract}
Bachtiar I, Hadi TA. 2019. Differential impacts of 2016 coral bleaching on coral reef benthic communities at Sekotong Bay, Lombok Barat, Indonesia. Biodiversitas 20: 570-575. Coral bleaching has been a major causal factor of coral mortality worldwide in the last two decades and it is therefore threaten food security. Understanding post-bleaching recovery is therefore very crucial to formulate strategy in promoting natural coral reef recovery. The present study documented coral reef communities both in pre- and post-bleaching event in early 2016. The results show that coral bleaching variably reduced coral and soft-coral covers. Sponge and other fauna cover considerably fluctuated. Since the individual number of soft-coral, sponge and other fauna were small, there is likely no big impact of coral bleaching. Among 12 study sites, 11 sites showed significant reduction of coral cover but one site showed only little fluctuation. Overall mean reduction of coral cover was about $18 \%$. Consequently, algal cover increased by about $24 \%$. The present study revealed differential coral bleaching impact between outer- and inner- reefs. At outer reefs, coral community suffered more severe mass coral mortality than those at inner reefs. This disparity is likely owing to initial coral cover and species composition of the coral communities. In the second year, there is still no visible coral recruitment from larvae. Cascade effects of land-clearing and overfishing due to increasing tourism development is very likely to be additional major stress that pause post-bleaching coral reef recovery at Sekotong Bay, Lombok Island, Indonesia.
\end{abstract}

Keywords: Climate change, habitat, fishery, food security, recovery

\section{INTRODUCTION}

Coral bleaching has been predicted long time to be a major problem for coral reef conservation on millennium era (Hoegh-Guldberg 1999), and it becomes evident in the recent bleaching event in 2016 (Hughes et al. 2017). Loss of coral cover may lead to reduction in fish biomass (Newman et al. 2006; Pratchett et al. 2008) that threaten food security. It was reported that in 2015-2016, bleachingdriven coral decline occurred globally, including in the middle and eastern Indonesia (Ampou et al. 2017), the Great Barrier Reef-Australia (Hughes et al. 2017), Red Sea (Monroe et al. 2018), Hawaii (Bahr et al. 2017) and Okinawa Island-Japan (Kayane 2017). This indicates that, although the reefs may have applied a good management system in preserving and conserving the coastal ecosystem, coral bleaching event is an inevitable human-induced natural disturbance which may turn the reefs to another state of non-Scleractinian dominated reefs and jeopardy sustainable fisheries.

Coral reef studies in Lombok Island were just started in late 1980s. Since then, coral reef in Lombok waters experienced three majors' coral bleaching, i.e., 1998, 2010 and 2016. The last three mass coral bleaching events ascertain that the rhythm of such natural disturbance is becoming faster. Lombok reefs had suffered bleaching event in 1998, causing severe coral mortality more than $90 \%$ in eastern Lombok Strait and down to southern
Lombok fringing reefs facing the Indian Ocean (Bachtiar 2001). Mass coral mortality in 2010 coral bleaching was not documented at Lombok Island, but mass coral mortality was reported to happen across Indonesian waters (Rudi et al. 2012; Wouthuyzen et al. 2015). Coral bleaching not only leads to mass coral mortality but also causes corals to be prone to diseases (Harvell et al. 2001; Muller et al. 2008; Rogers and Muller 2012).

Post-bleaching recovery of coral community is very dependent on management status and practice of the coral reefs, but it usually takes several years to decades to reach a similar level of coral cover (Graham et al. 2011) and the same level of biodiversity (Brown and Suharsono 1990; Warwick et al. 1990). However, previous studies confirmed that the composition of coral communities from recovered reefs was different to the previous state prior to bleaching event (Diaz-Pulido et al. 2009; Mumby \& Harborne 2010). Thus, understanding the post-disturbance of bleaching event is necessary to provide the current state and the potential recovery of the reefs.

Coral reefs at eastern side of Lombok Strait, Indonesia, had been cracked again by mass coral bleaching on MarchMay 2016. The bleaching affected corals at Sekotong Bay reefs which are spread in several small islands. This paper describes changes in coral reef benthic community before and after bleaching event, and to explore differential bleaching impacts between inner- and outer- reefs. 

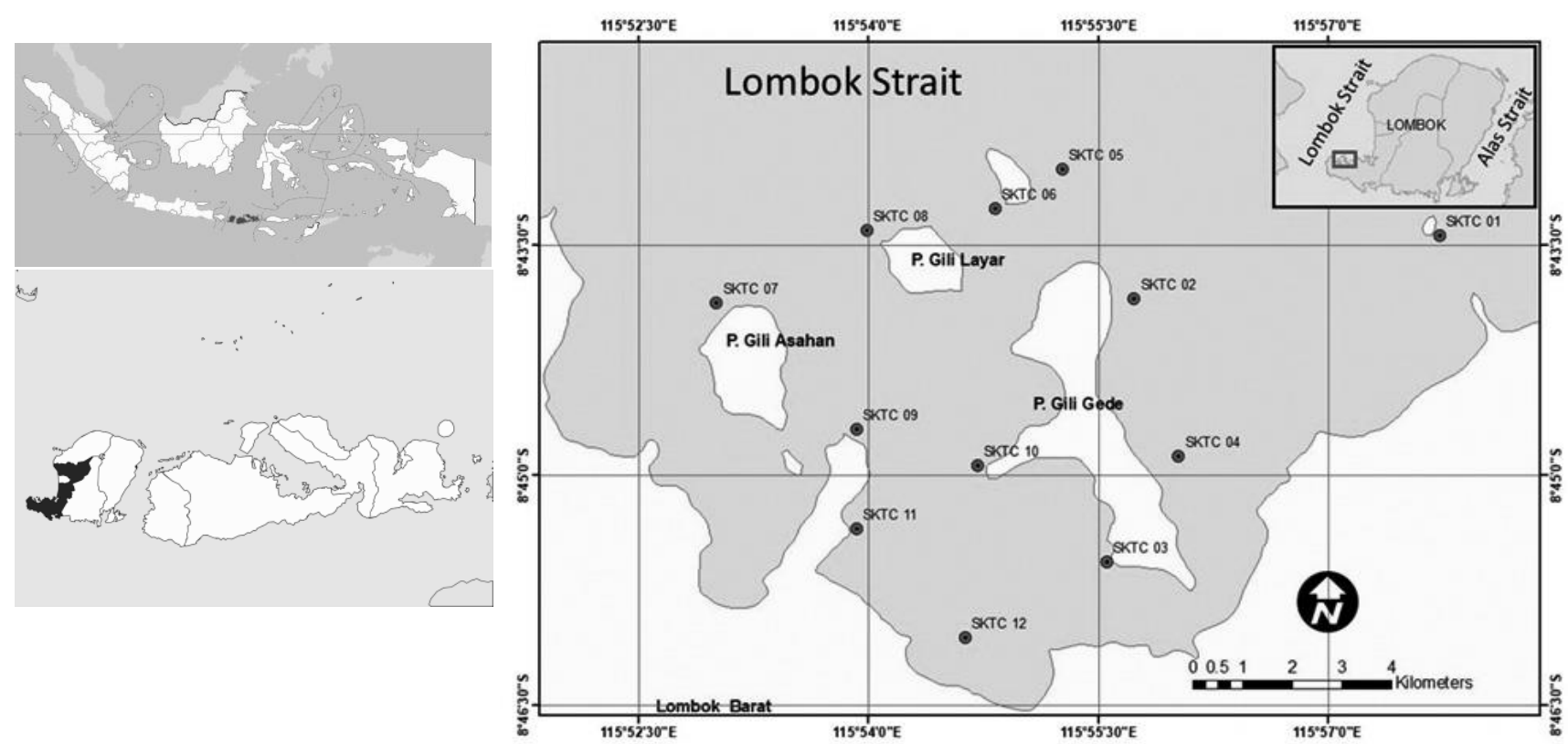

Figure 1. Location of the monitoring sites at Sekotong Bay, Lombok Island, Indonesia

\section{MATERIALS AND METHODS}

\section{Study area}

The study was carried out at north of Sekotong waters (Sekotong Bay), District of Lombok Barat, Indonesia (Figure 1). The study was part of a regular annual coral reef monitoring program of the COREMAP-CTI that is running from 2015 to 2019. Coral reefs of Sekotong Bay may be divided into two major groups, inner- and outer- reefs. Outer reefs directly adjoined with Lombok Strait. They have therefore better water clarity, with visibility $>10$ meters. In contrast, inner reefs disconnected with Lombok Strait that they have more turbid water with lower visibility, mostly 4-5 meter. The inner reefs have high suspended sediments that mostly consist of sand and silt. The outer reefs consist of Gili Lontar (SKTC 01), Gili Anyaran (SKTC 05), Gili Rengit (SKTC 06), Gili Asahan (SKTC 07) and Gili Layar (SKTC 08). The inner reefs comprise four reefs at Gili Gede (SKTC 02, SKTC 03, SKTC 04, SKTC 10), three reefs in Lombok Island (SKTC 09, SKTC 11, SKTC 12).

\section{Procedures}

There were 12 monitoring sites (SKTC 01 to SKTC 12) with permanent transects $(50 \mathrm{~m}$ length) installed parallel to the coastline at the depth of around 5 meters in the slope areas. Each transect was marked with iron sticks set at meter $0,10,20,30,40$ and 50; and with fishing-lines (diameter $3 \mathrm{~mm}$ ) fitted between the sticks and following the contour of the reefs. These markings are to ensure that the monitoring would take place at the same points to improve the accuracy. A portable GPS was also used onboard to find back the locations of the transects.

Data on coral reef benthic communities were collected using an underwater photo transects (UPT) method with a $44 \times 58 \mathrm{~cm}^{2}$ iron frame. The frame was placed at meter 1 ,
2, 3 until 50 in an alternating pattern; up and downside of the transect line for odd and even numbers respectively (Giyanto 2012). Benthic coverage data were generated from each framed photo using a special soft-ware CPCe 4.1 (Kohler and Gill 2006). All benthic communities recorded then were categorized into 13 functional groups as described in English et al. (1994).

Data collections on monitoring sites were performed in November 2015, July-August 2016 and July-August 2017. By accident, we have data on coral reef benthic communities before and after bleaching event in early 2016. Coral started bleaching in late February 2016. Temperature record from data loggers on nearby island (Benete Bay, Sumbawa) with similarity in facing to the Indian Ocean shows $31^{\circ} \mathrm{C}$ of seawater temperature since February for several weeks, while annual maximum temperature is $30^{\circ} \mathrm{C}$ (unpublished data) in the last six years period.

\section{Data analysis}

The pre- and post-bleaching data were collected in November 2015 and August 2016 respectively. Data were found to show normal distribution and various homogeneities that were suitable for parametric statistical analysis. Comparison of coral cover averages was carried out using analysis of variance (ANOVA). Tukey HSD test was applied to determine significant differences among years.

\section{RESULTS AND DISCUSSION}

In general, benthic communities were changing very much during the monitoring period. A dramatic decline in coral cover was detected between 2015 and 2016, decreased by $18 \%$ from average $( \pm \mathrm{SD})$ coral cover 
$36.09 \pm 17.08 \%$ in 2015 to $18.23 \pm 13.99 \%$ in 2016 . In the following year, coral cover declined slightly to $14.61 \pm 10.46 \%$ in 2017 (Figure 2). Overall relative coral mortality was $50 \%$ due to bleaching in early 2016. Coral cover averages are significantly different between 2015 to 2016 and 2015 to 2017 (Table 1). Between the last two years, 2016-2017, coral cover is about the same. Continuing reduction of coral cover in 2017 has, therefore, no significant ecological effect on coral communities.

Consequently, algae occupied empty spaces on dead corals and rubbles resulted in increase of algal cover. Between 2015-2016, dead corals with algae increased by $24 \%$, from $24.97 \pm 4.93 \%$ to $49.25 \pm 20.00 \%$, while in the upcoming year the percent cover continually increased by $19.34 \%$. In this case, spaces in the quadrate frame occupied previously by corals were then covered by algae, particularly turf algae and microalgae. Beside decline in coral cover, the increase of algal cover also coincided with the decline in rubbles and other fauna covers.

At Sekotong Bay, the impact of bleaching was worse than in other reefs of Indonesia. In 2017, 10 out of 12 reefs were in poor category $(<25 \%$ coral cover $)$. This was in contrast to 2015 condition which was only 4 reefs in poor category, the other 3 reefs in good category $(\geq 50 \%$ coral cover) and 5 reefs in fair category $(25 \% \leq$ coral cover $<$ $50 \%$ ). Overall, about $25 \%$ good category reefs and $50 \%$ fair category reefs have shifted to lower levels due to 2016 bleaching event. In Indonesia, the number of good coral reefs declined from bleaching was roughly $5 \%$, whereas the poor and fair coral reef categories increased roughly by 5 $\%$ (Giyanto et al. 2017).

Soft corals and sponges also experienced decline in the percent covers from 2015 to 2016. Since their prebleaching percent covers were very small $(<10 \%)$, soft coral and sponge declines are not ecologically significant. In contrast, coral loss and algal increase, however, would have significant effect on the ecosystems. In this case, a phase shift to algal-dominated reefs can affect the composition of reef-associated biota, such as benthos and fishes (Done 1992; Cheal et al. 2010). Other benthic fauna found in 2016 but then disappeared in 2017 were crinoids and ascidians.

There were differential coral bleaching impacts between inner and outer reefs. The outer reefs showed $63 \%$ relative decline in coral cover, while inner reefs only suffered $45 \%$ relative coral cover decline. Absolut coral cover lost was about three times higher at outer reefs than at inner reefs. Sponge and soft coral covers were fluctuated at outer reefs but nearly absent at inner reefs during three years study. In contrast, rubble cover continually decreased during the period at inner reefs, as it was slowly covered by algae in 2017. At outer reefs, rubble cover was very small in 2015, and it was then covered by encrusting sponges in 2017.

The first reason for the difference in coral cover decline between the reefs is the composition of benthic communities. In general, fast-growing branching corals (Acropora, Seriatopora, Stylophora, Millepora, and Pocillopora) are more vulnerable to the elevated seawater temperature compared to slow-growing massive corals
(Favites, Favia, Turbinaria, Goniastrea, Astreopora and Porites) (Floros et al. 2004; McClanahan et al. 2004). On the outer reefs of Sekotong, predominant branching corals, Acroporidae, mostly suffered from severe bleaching-related mass mortality. Several acroporid colonies, however, were still found among coral survivors at these sites, i.e., Acropora aspera, A. formosa, A. hyacinthus, A. divaricata, $A$. palifera, and A. microphthalma. Other surviving taxa on the outer reefs are colonies of Pocillopora verrucosa, Porites cylindrica, Oxypora lacera, Echinopora lamellosa, E. horrida and massive corals Porites spp. At SKTC06 and SKTC08, some colonies of A. formosa were found dead and covered with algae, but adjacent coral colonies of the same species were survived. The same phenomena also happened with the coral Echinopora lamellosa at SKTC08.

Table 1. Statistical analysis to compare coral cover in the last three years

\begin{tabular}{lcccc}
\hline Comparison & Statistics & & df & Inference \\
\hline Inter-years & $\mathrm{F}=27.797$ & & 2 dan 22 & $\mathrm{P}<0.01$ \\
Between 2015-2016 & $\mathrm{q}=8.193$ & 2 dan 22 & $\mathrm{P}<0.05$ \\
Between 2015-2017 & $\mathrm{q}=9.853$ & 2 dan 22 & $\mathrm{P}<0.05$ \\
Between 2016-2017 & $\mathrm{q}=1.659$ & 2 dan 22 & $\mathrm{P}>0.05$ \\
\hline
\end{tabular}

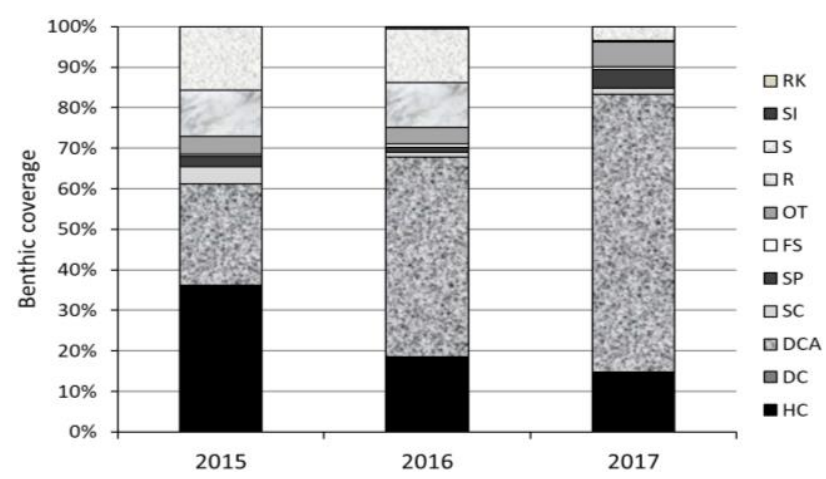

Figure 2. Changes on coral reef benthic communities after coral bleaching in early 2016. HC=hard corals, DC=dead corals, $\mathrm{DCA}=$ dead corals covered algae, $\mathrm{SC}=$ soft corals, $\mathrm{SP}=$ sponge, $\mathrm{FS}=$ fleshy seaweed, OT=other fauna, $\mathrm{R}=$ rubble, $\mathrm{S}=$ sand, $\mathrm{SI}=$ silt, $\mathrm{RK}=$ rock

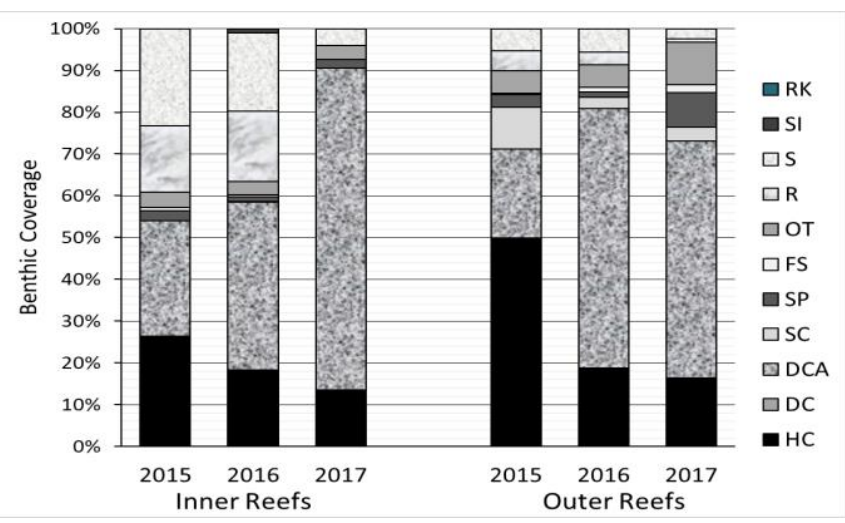

Figure 3. Changes on coral reef benthic covers at inner- and outer- reefs of Sekotong Bay in three year period. $\mathrm{HC}=$ hard corals, DC $=$ dead corals, DCA=dead corals covered algae, $\mathrm{SC}=$ soft corals, $\mathrm{SP}=$ sponge, $\mathrm{FS}=$ fleshy seaweed, $\mathrm{OT}=$ other fauna, $\mathrm{R}=$ rubble, $\mathrm{S}=$ sand, $\mathrm{SI}=$ silt, $\mathrm{RK}=$ rock 


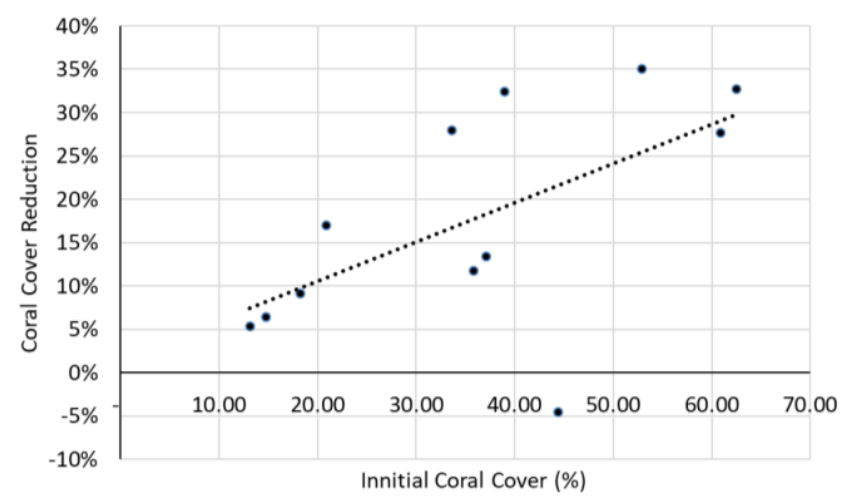

Figure 4. Relationship between initial coral cover and coral cover reduction due to bleaching event

On the inner reefs, surviving corals were mostly (96\%) non-Acroporid corals. Coral reefs with predominant nonAcroporid corals suffered fewer declines in coral covers. SKTC03, SKTC10, SKTC 11 showed small decline $(<5 \%)$ in post bleaching coral cover, while SKTC12 even showed small increase in coral cover. Surviving coral genera in the first group were massive corals Porites, Physogyra and Goniastrea. In SKTC12, predominant coral cover was Porites cylindrica. Other surviving coral genera were Favites, Hydnophora and Fungia. Colonies of branching coral Seriatopora caliendrum were also found with the surviving colonies in all inner reefs. Hence, although it was found that not all fast-growing branching corals suffered from the bleaching, it is obvious that the coral community composition very likely determines the vulnerability of the reefs to the bleaching event.

When coral community is predominated by fastgrowing corals, such as Acroporidae, coral mortality due to bleaching is strongly correlated with its initial cover. Coral reefs with higher coral cover suffered more than one with less coral cover. The reef that was not fit with this hypothesis was SKTC 12, which was predominated by Porites cylindrica. Outlier data of SKTC12 was then set aside in the regression analysis. The simple linear regression shows that the relationship between the reduction in coral cover and pre and post-bleaching event is modest $\left(\mathrm{r}^{2}=0.635\right)$, but highly significant $(\mathrm{P}<0.01)$. This result shows that when predominance corals were not Porites spp. (e.g., SKTC12), magnitude impact of coral bleaching depends on its previous coral cover (Figure 4).

Corals at station SKTC12 showed the highest coral survivors at Sekotong waters. Coral communities at this reef have three advantages. Firstly, it is predominated by Porites cylindrica, which has been known as among the most resistant to bleaching (Marshall \& Baird 2000; Wooldridge 2014). Secondly, the environmental condition of SKTC12 is very turbid; indicating total suspended sediment (TSS) is very high. Cacciapaglia and van-Woesik (2016) reported that turbidity reduced irradiance and contributed to coral resistance to bleaching in 12 species of Indian and Pacific Oceans. Furthermore, corals at SKTC12 may also receive significant effluent of tannin-containing water from adjacent mangroves. It has been suspected that tannin can also reduce UV exposure on corals. The role of tannin in coral bleaching resistance is still lack of studies.

In the last three bleaching events (1998, 2010, 2016), corals of small island reefs spread along the eastern side of Lombok Strait (Sekotong, Senggigi and Gili Matra) were more vulnerable than at Nusa Lembongan (western Lombok Strait) and Gili Sulat (western Alas Strait). Coral mortality rate due to the bleaching event is much lower at Nusa Lembongan and Gili Sulat than Sekotong reefs. Both Nusa Lembongan and Gili Sulat have wide area of mangroves which apparently benefit to coral reefs. Mangrove ecosystem exports dissolved tannin to its adjacent waters (Lopez-Portillo et al. 2017). Tannin may serve as sunblock layers that may reduce ultraviolet irradiance during hot thermal stress. It is therefore important to further study the effect of tannin on coral bleaching resistance.

Recovery of post-bleaching event varies among reefs. In Singapore, $16 \%$ recovery of coral cover took approximately 10 years after bleaching (Guest et al. 2017). At a remote Solitary Island (Australia), coral cover bounced back to its previous state after 12 years with two years recruitment delay (Gilmour et al. 2013). The two cases took place in areas where anthropogenic stress is set aside or has no access to the reefs. In other well-managed reefs, the Great Barrier Reef, coral bleaching in 2000 reduced coral cover from $28 \%$ to $3 \%$ in 2005 and coral cover was still 6\% in 2008 (Pratchett et al. 2008).

Recovery of coral cover at reefs of Sekotong Bay might take a longer time than the reefs of Singapore and the Solitary Island. Anthropogenic stress is still increasing as tourism industry has been developing at Sekotong Bay. Tourism industry development has brought negative impact to environment, given that terrestrial run-off becomes so evident due to accommodation development on coastal areas and nearby highland. Vegetation clearing for agriculture has been a major source of sediment run-off to Sekotong Bay. Increasing number of accommodations on denuded hills surrounding Sekotong Bay increases sediment upload to the reefs. Abandoned traditional mineland is also aggravating sedimentation. Sedimentation has been reported to reduce coral larval settlement and survivorship (Hodgson 1990). Both sedimentation and nutrient run-off reduce coral reef resilience.

Ecosystem resilience is highly dependent on structural legacy, biological legacy and mobile link (larval dispersal and reef connectivity) (Lundberg \& Moberg 2003). In general, coral reefs at Sekotong do not show overall significant structural changes from the last bleaching event. However, a massive structural change was found only at SKTC01 and SKTC05. In this case, pre-bleaching communities which were predominantly branching Acroporidae turned to consolidated coral rubbles colonized by turf algae in the aftermath. This type of benthic cover could be colonized by drifted coral larvae when herbivory still in place (Hughes 1994; Bellwood et al. 2004). Another structural change occurred at SKTC05 (Gili Anyaran) where consolidated rubbles were colonized by another benthos, soft corals. Growing soft corals may further delay 
recovery of coral cover (Atrigenio and Alino 1996; Fox et al. 2003).

Biological legacy is also thought to be still present to some extent. Several coral colonies of Poritidae, Pocilloporidae, Favidae, and Acroporidae survived from the bleaching. These colonies may produce planula larvae that are recruited locally (Adjeroud et al. 2007). Acroporid corals may also produce asexual offspring from its colony fragments. Local asexual coral recruitment was apparent in coral Seriatopora hystrix, S. caliendrum and Echinopora lamellosa at some sites. Such recruitment may significantly change community structure in favor of coral species with pioneering life-strategy (Bachtiar et al. 2012).

It is expected that larval dispersal and reef connectivity will enhance coral recruitment in near future. A very long coral larval competency has been reported in Pocillopora damicornis for 103 days (Richmond 1988) and 195-244 days in Acropora latistella, Favia pallida, Pectinia paeonia, Goniastrea aspera, and Montastraea magnistellata (Graham et al. 2008). Those long larval competencies potentially support larval recruitment of Sekotong reefs from far distance reefs. Coral reefs of Sekotong potentially may receive larvae supply from northern reefs, as Indonesian Through flow current passes the Lombok Strait predominantly moves southward into the Indian Ocean (Arief and Muray 1996). Presumably, coral larval sources are coral reefs at Senggigi, Gili Meno, or even Kapoposang Islands (South Sulawesi). Coral survivors at the first two locations are about the same level as those at Sekotong Bay, as they are all situated at eastern side of Lombok Strait. There is no information about coral survivors in Kapoposang Island so far.

In general, the 2015-2016 bleaching event affected the condition of coral reefs at Sekotong to decline. Coral mass mortality due to bleaching will upset fish biomass both in short term (Newman et al. 2006; Pratchett et al. 2008) and long-term (Kajsa et al. 2006). Decline of structural complexity is the main factor leading to reduction in fish abundance and biomass. Since coral reef fishery is the second most important livelihood of Sekotong coastal community, coral bleaching in some way may reduce local economy and fish catch per unit effort. Impact of coral bleaching on food security and self-sufficiency should be mitigated by reducing anthropogenic stress on reefs. In Sekotong Bay, coral reef management should be encouraged to emphasis more to tourism use of coral reefs and reduction of spearfishing.

\section{ACKNOWLEDGEMENTS}

This paper is supported by USAID through Sustainable Higher Education Research Alliances (SHERA) Program Center for Collaborative Research Animal Biotechnology and Coral Reef Fisheries (CCR ANBIOCORE). Dive trips would never be accomplished without financial support of the COREMAP-CTI. We also express our gratitude to the local government for the permit and favors during the field work. Fieldwork assistances also came from UKM Riset Kelautan dan Perikanan, Universitas Mataram.

\section{REFERENCES}

Adjeroud M, Penin L, Carroll A. 2007. Spatio-temporal heterogeneity in coral recruitment around Moorea, French Polynesia: Implications for population maintenance. J Exp Mar Biol Ecol 341:204-218.

Ampou EE, Johan O, Menkes CE, Nino F, Birol F, Ouillon S, Andrefouet S. 2017. Coral mortality induced by the 2015-2016 El-Nino in Indonesia: the effect of rapid sea level fall. Biogeosciences 14: 817826.

Arief D, Murray SP. 1996. Low-frequency fluctuations in the Indonesian throughflow through Lombok Strait. J Geophys Res 101(65):1245512464

Atrigenio MP, Alino PM. 1996. Effects of the soft coral Xenia puertogalerae on the recruitment of scleractinian corals. J Exp Mar Biol Ecol 203: 179-189

Bachtiar I. 2001. Promoting recruitment of scleractinian corals using artificial substrate in the Gill Indah, Lombok Barat, Indonesia. Proceedings $9^{\text {th }}$ International Coral Reef Symposium, Bali, Indonesia 23-27 October 2000.

Bachtiar I, Abrar M, Budiyanto A. 2012. Recruitment of scleractinian corals at Lembata Island waters. Ilmu Kelautan 17(1): 1-7. [Indonesian]

Bahr KD, Rodgers KS, Jokiel PL. 2017. Impact of three bleaching events on the reef resiliency of Kāne'ohe Bay, Hawai'i. Front Mar Sci. https://doi.org/10.3389/fmars.2017.00398

Bellwood DR, Hughes TP, Folke C, Nyström M. 2004. Confronting the coral reef crisis. Nature 429: 827-833.

Brown BE, Suharsono. 1990. Damage and recovery of coral reefs affected by El Nino related seawater warming in the Thousand Islands, Indonesia. Coral Reefs 8: 163-170.

Cacciapaglia C, van Woesik R. 2016. Climate-change refugia: shading reef corals by turbidity. Glob Change Biol 22:1145-1154

Cheal AJ, MacNeil MA, Cripps E, Emslie MJ, Jonker M, Schaffelke B, Sweatman H. 2010. Coral-macroalgal phase shifts or reef resilience: links with diversity and functional roles of herbivorous fishes on the Great Barrier Reef. Coral reefs 29: 1005-1015.

Diaz-Pulido G, McCook LJ, Dove S, Berkelmans R, Roff G, Kline DI, Weeks S, Evans RD, Williamson DH, Guldbergh OH. 2009. Doom and boom on a resilient reef: climate change, algal overgrowth and coral recovery. Plos One 4: e5239. https://doi.org/10.1371/journal.pone.0005239

Done TJ. 1992. Phase shifts in coral reef communities and their ecological significance. Hydrobiologia 247: 121-132.

Floros CD, Samways MJ, Armstrong B. 2004 Taxonomic patterns of bleaching within a South African coral assemblage. Biodivers Conserv 13: 1175-1194.

Fox HE, Pet JS, Dahuri R, and Caldwell RL. 2003. Recovery in rubble fields: long-term impacts of blast fishing. Mar Poll Bull 46: 10241031

Gilmour PJ, Smith LD, Heyward AJ, Baird AH, Pratchett MS. 2013. Recovery of an isolated coral reef system following severe disturbance. Science 340: 69-71.

Giyanto. 2012. Assessment of coral reef condition using underwater photo transect. Oseanologi dan Limnologi di Indonesia 38: 377-389. [Indonesian]

Giyanto, Abrar M, Hadi TA, Budiyanto A, Hafizt M, Salataholy A, Iswari MY. 2017. Status of Indonesian Coral Reefs. Pusat Penelitian Oseanografi LIPI, Jakarta. [Indonesian]

Guest JR, Tun K, Low J, Vergés A, Marzinelli EM, Campbell AH, Bauman AG, Feary DA, Chou LM, Steinberg PD. 2016. 27 years of benthic and coral community dynamics on turbid, highly urbanized reefs off Singapore. Sci Rep 6: 36260.

Graham EM, Baird AH, Connolly SR. 2008. Survival dynamics of scleractinian coral larvae and implications for dispersal. Coral Reefs 27(3): 529-539.

Graham NAJ, Nash KL, Kool JT. 2011. Coral reef recovery dynamics in a changing world. Coral Reefs 30: 283-294

Harvell D, Kim K, Quirolo C, Weor J, Smith G. 2001. Coral bleaching and disease: contributors to 1998 mass mortality in Briareum asbestinum (Octocorallia, Gorgonacea). Hydrobiologia 460: 97-104.

Hoegh-Guldberg O. 1999. Climate Change, coral bleaching and the future of the world's coral reefs. Mar Freshwater Res 50: 839-866

Hodgson G. 1990. Sediment and the settlement of larvae of the reef coral Pocillopora damicornis. Coral Reefs 9: 41-43. 
Hughes TP. 1994. Catastrophes, phase shifts and large-scale degradation of Caribbean coral reef. Science 65: 1547-1551

Hughes TP, Kerry JT, Álvarez-Noriega M, et al. 2017. Global warming and recurrent mass bleaching of corals. Nature, 543(7645): 373-377.

Kajsa C, Garpe KC, Yahya SAS, Lindahl U, Marcus C, Öhman MC 2006. Long-term effects of the 1998 coral bleaching event on reef fish assemblages. Mar Ecol Prog Ser 315: 237-247

Kayane H. 2017. Validation of degree heating weeks as a coral bleaching index in the northwestern Pacific. Coral Reefs 36: 63-70.

Kohler KE, Gill M. 2006. Coral point count with excel extensions (CPCe): a visual basic program for the determination of coral and substrate coverage using random point count methodology. Comput Geosci 32: 1259-1269.

Lopez-Portillo J, Lara-Domínguez AL, Vázquez G, Aké-Castillo JA 2017. Water quality and mangrove-derived tannins in four coastal lagoons from the Gulf of Mexico with variable hydrologic dynamics . J Coast Res: Special Issue 77: 28-38.

Lundberg J, Moberg F. 2003. Mobile link organisms and ecosystem functioning: implications for ecosystem resilience and management. Ecosystems 6:87-98.

Marshall P, Baird AH. 2000. Bleaching of corals on the Great Barrier Reef: differential susceptibilities among taxa. Coral Reefs 19: 155163.

Monroe AA, Ziegler M, Roik A, Rothig T, Hardenstine RS, Emms MA, et al. 2018. In situ observations of coral bleaching in the central Saudi Arabian Red Sea during the 2015/2016 global coral bleaching event. PloS One 13(4): e0195814. DOI: 10.1371/journal.pone.0195814

Muller EM, Rogers CS, Spitzack AS, van Woesik R. 2008. Bleaching increases likelihood of disease on Acropora palmata (Lamarck) in Hawksnest Bay, St John, US Virgin Islands. Coral Reefs 27: 191-195.
Mumby PJ, Harborne AR. 2010. Marine reserves enhance the recovery of corals on Caribbean Reefs. Plos One 5: e8657. https://doi.org/10.1371/journal.pone.0008657

Pratchett MS, Baird AH, McCowan DM, Coker DJ, Cole AJ, Wilson SK. 2008. Protracted declines in coral cover and fish abundance following climate-induced coral bleaching on the Great Barrier Reef. Proceedings of the $11^{\text {th }}$ International Coral Reef Symposium, Ft Lauderdale, Florida, 7-11 July 2008.

Richmond HR. 1988. Competency and dispersal of planullae larvae of a spawning versus a brooding coral. In: Choat $\mathrm{JH}$, Barnes D, Borowitzka MA, et al. (eds.) Proceeding of the $6^{\text {th }}$ International Coral Reef Symposium, Townsville, Australia, 8-12 August 1988.

Rogers CS, Muller EM. 2012. Bleaching, disease and recovery in the threatened scleractinian coral Acropora palmata in St. John, US Virgin Islands: 2003-2010. Coral Reefs 31: 807-819.

Rudi E, Iskandar T, Fadli N, Hidayati H. 2012. Impact of mass coral bleaching on reef fish community and fishermen catches at Sabang, Aceh Province, Indonesia. AACL Bioflux 5: 309-320.

Warwick RM, Clarke KR, Suharsono. 1990. A statistical analysis of coral community responses to the 1982-83 El Nino in the Thousand Islands, Indonesia. Coral Reefs 8: 171-179.

Wooldridge SA. 2014. Differential thermal bleaching susceptibilities amongst coral taxa: re-posing the role of the host. Coral Reefs 33: 1527.

Wouthuyzen S, Abrar M, Lorwens J. 2015. Coral bleaching event in 2010 at Indonesian waters using sea surface temperature. Oseanologi dan Limnologi di Indonesia 1: 305-327. [Indonesian]. 